\title{
Isoelectric points of urinary light chains in myelomatosis: analysis in relation to nephrotoxicity
}

\author{
EA JOHNS,* R TURNER,* EH COOPER,* ICM MACLENNAN $\dagger$ \\ From the *Unit for Cancer Research, University of Leeds, Leeds, and the †Department of Immunology, \\ University of Birmingham Medical School, Birmingham
}

SUMMARY Measurements of the isoelectric point ( $\mathrm{pI}$ ), sialic acid content, and polymerisation were made of 43 light chains isolated from the urine of patients with myelomatosis excreting large amounts of light chains. The pIs ranged from 3.5-9.5, and 23 were $>7 \cdot 0$. Sialylation was detected in $62 \%$ of light chains, and $69 \%$ showed microheterogeneity of charge. There was no clear association between the pI, sialylation, or polymerisation and the presence of renal failure, as assessed by serum creatinine concentrations. Light chains with pI spectrotype in the basic range, however, were found to produce more proximal tubular dysfunction than acidic light chains.

Free light chains in the plasma are removed from the circulation by filtration through the glomerulus and catabolised in the proximal tubular cells ${ }^{12}$; their clearance and catabolism is similar to several other serum low molecular weight proteins. ${ }^{3}$ In multiple myeloma the concentration of free light chains cleared through the glomeruli often exceeds the tubular reabsorption threshold so that they appear in abnormal concentrations in the urine (Bence-Jones proteinuria). The presence of light chains in the urine is accompanied by an impairment of proximal tubular reabsorption of other low molecular weight proteins and this is accentuated as the glomerular filtration rate falls when indicated by a rising concentration of serum creatinine. ${ }^{4}$ Some patients show severe renal impairment with a relatively low urinary free light chain concentration. Conversely, a few patients excrete very large amounts of free light chain with little or no impairment of glomerular function.

It has been suggested that the isoelectric point (pI) of light chains may be an important factor for determining the nephrotoxic potential of these proteins, ${ }^{56}$ although studies of the cause of nephropathy, using a light chain producing tumour transplanted into rats, have cast doubt on this hypothesis. ${ }^{7}$ Our preliminary studies of high performance chromatography of Bence-Jones proteins indicated that individual monoclonal proteins could be heterogeneous with respect to their charge ${ }^{8}$; and this has recently been confirmed by isoelectric focusing with immunofixation. ${ }^{9}$

In this study we identified various physicochemical characteristics of urinary free light chains in patients

Accepted for publication 18 March 1986 with myelomatosis who were excreting large amounts of light chain at the time of presentation. The objective was to examine whether there is a correlation between the character of the light chains in the urine and impaired renal function.

\section{Patients and methods}

Forty three untreated patients with myelomatosis whose excretion of urinary light chains exceeded $>3 \mathrm{U} / \mathrm{l}$ (IU $=1 \mathrm{lg}$ polyclonal light chains standard; this standard is known to underestimate or overestimate the weight of light chains in certain monoclonal light chains) were selected for study from the Medical Research Council's Vth Myeloma Trial. They were divided into the functional groups based on those used in an earlier study ${ }^{10}$; (A) creatinine $<150 \mu \mathrm{mol} / 1(1.69 \mathrm{mg} / 100 \mathrm{ml})$ at presentation and remaining below this level; (B) creatinine $>150 \mu \mathrm{mol} / 1$ at presentation falling to $<150 \mu \mathrm{mol} / 1$ on treatment; (C) creatinine $>150 \mu \mathrm{mol} / 1$ improving on treatment but remaining $>150 \mu \mathrm{mol} / \mathrm{l}$; and (D) creatinine $>150 \mu \mathrm{mol} / 1$ rising or remaining unchanged despite treatment. In addition, patients who died within 100 days of presentation were analysed separately and excluded from groups A-D.

The relevant data about the urinary light chain type and concentration, serum paraprotein concentration, and serum creatinine concentration were obtained using the methods previously described. ${ }^{10}$ The urinary $\alpha l$-microglobulin concentration was measured by radial immunodiffusion. ${ }^{4}$ 
ISOLATION OF LIGHT CHAINS

The urinary free light chains were isolated using a Pharmacia AB (Uppsala, Sweden) fast protein liquid chromatography (FPLC) system. Anion-exchanged chromatography was performed on a Mono Q HR5/5 column, and cation-exchange chromatography was performed on a Mono S HR5/5 column.

The Mono $Q$ column was equilibrated with $6.25 \mathrm{mM}$ bis Tris propane buffer, $\mathrm{pH} 7.5(\mathrm{~A})$ and the elution buffer (B) was $6.25 \mathrm{mM}$ bis Tris propane buffer containing $0.35 \mathrm{M}$ sodium chloride $(\mathrm{pH} 9.5)$. A uniform elution gradient from $0 \% \mathrm{~A}$ to $100 \% \mathrm{~B}$ was produced over $20 \mathrm{ml}$. The Mono $\mathrm{S}$ column was equili-

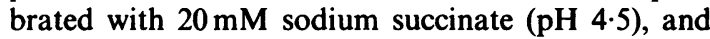
the elution buffer was $20 \mathrm{mM}$ sodium succinate containing $0.35 \mathrm{M}$ sodium chloride: the gradient was the same for the Mono Q. Both these columns were run at a flow rate of $1.0 \mathrm{ml} / \mathrm{minute}$.

\section{CHROMATOGRA PHIC SEQUENCE}

The urine samples were desalted by chromatography on a Sephadex G25 column using the equilibration buffer for the Mono $Q$ column. An aliquot was then chromatographed on the Mono $Q$ column and the fractions collected. Most of the light chains were retained on the column, although some, usually the more basic types eluted in the void volume. Those that were not retained on the Mono $Q$ column were rechromatographed on a Mono $S$ after dialysis against the Mono S start buffer. The $\kappa$ and $\lambda$ light chains in chromatograms with complex peaks were identified by immunoprecipitation using specific antisera on Ouchterlony plates.

\section{AFFINITY CHROMATOGRAPHY}

Light chains that had complex patterns on the ion exchangers were also isolated by affinity chromatography using immobilised monoclonal anti- $\kappa$ light chain antibodies linked to Sepharose 4B or monoclonal anti- $\lambda$ light chain antibodies, both affinity gels. Desalted urine proteins were applied to the column in $0.1 \mathrm{M}$ Tris $(\mathrm{pH} 8.0$ ) containing $0.5 \mathrm{M}$ sodium chloride and $0.1 \%$ sodium azide and eluted with $3 \mathrm{M}$ potassium thiocyanate. Comparison of the FPLC and affinity methods of isolation showed that the same light chains gave similar pI spectrotypes with either method of isolation.

\section{ASSESSMENT OF LIGHT CHAIN GLYCOSYLATION} AND POLYMERISATION

The size of purified light chains was assessed by sodium dodecyl sulphate polyacrylamide gel electrophoresis (SDS-PAGE) using $10 \%$ vertical slab gels prepared according to the method of Laemmli. ${ }^{11}$ Samples were dissolved in Tris-SDS sample buffer and boiled for five minutes with or without $1 \%$

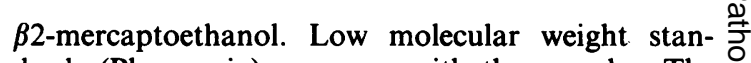

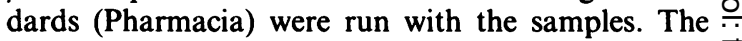
gels were stained for protein with $0.1 \%$ PAGE blue $83 \overrightarrow{\overrightarrow{\mathrm{S}}}$ (British Drug Houses, Poole, Dorset) dissolved in methanol:acetic acid:water (3:1:6). The sialic acid content was measured by the thiobarbiturate method $\frac{\sigma}{\bar{\sigma}}$ of Warren. ${ }^{12}$

MEASUREMENT OF URINARY LIGHT CHAIN PI SPECTROTYPE

Isoelectric focusing was performed in $1 \mathrm{~mm}$ thick $5 \%$ polyacrylamide gels containing $6.4 \%$ Pharmalyte $\vec{\omega}$ 3-10. The gels were fixed in a mixture of $10 \%$ trichloroacetic acid and $5 \%$ sulphosalicylic acid for one hour and washed overnight in destain (methanol: acetic acid:water $5: 1: 14)$. The protein bands were $\%$ stained with PAGE blue $83,0.1 \%$, in destain. The isoelectric points of the light chain bands were deter- $\omega$ mined from the positions of the marker proteins (broad pI calibration kit, Pharmacia) was run in the same gel.

\section{Results}

Fig. 1 shows the spectrotypes of urinary light chain pIs. Sialic acid was detected in 26 of $42(61.9 \%)$ sam- $\square$ ples. Fig. 1 shows the level of sialylation of the light chains and indicates that sialylation cannot be the only cause of the charge of heterogeneity.

Parallel studies of the same light chain isolated by an ion exchange chromatography and immunosorbent chromatography gave similar levels of sialylation and microheterogeneity of $\mathrm{pI}$.

\section{LIGHT CHAIN PI AND THE PRESENCE OF RENAL}

\section{FAILURE}

The results were ranked by serum creatinine, assessed before starting cytotoxic chemotherapy but after $48 \underline{3}$ hours of hydration. There was no obvious association $\delta$ between this measure of renal failure and light chain pI. This series contained three cases of IgDk, which is 을 an exceptionally high incidence of this rare form of $D$ myelomatosis. These patients, however, were among the high light chain excretors from the 400 patients $\mathrm{N}$ examined.

\section{LIGHT CHAIN PI AND PROXIMAL TUBULAR DYSFUNCTION} It has been shown previously that patients with light chain proteinuria show objective evidence of selective $\frac{}{\mathrm{D}}$ proximal tubular dysfunction. This evidence included $\stackrel{\oplus}{+}$ failure to reabsorb the low molecular weight protein $\tau$ $\alpha 1$-microglobulin $[\alpha 1-\mathrm{m}] .^{4}$ There is a correlation $\bar{O}$ between urinary $\alpha 1-\mathrm{m}$ and light chain excretion. ${ }^{10} \mathbb{\mathbb { D }}$ Some patients, however, have less impairment of $\overrightarrow{\mathbb{D}}$ tubular reabsorption of $\alpha 1-m$ than others with $\frac{a}{\sigma}$ 


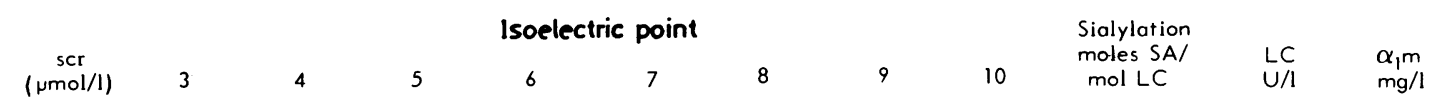

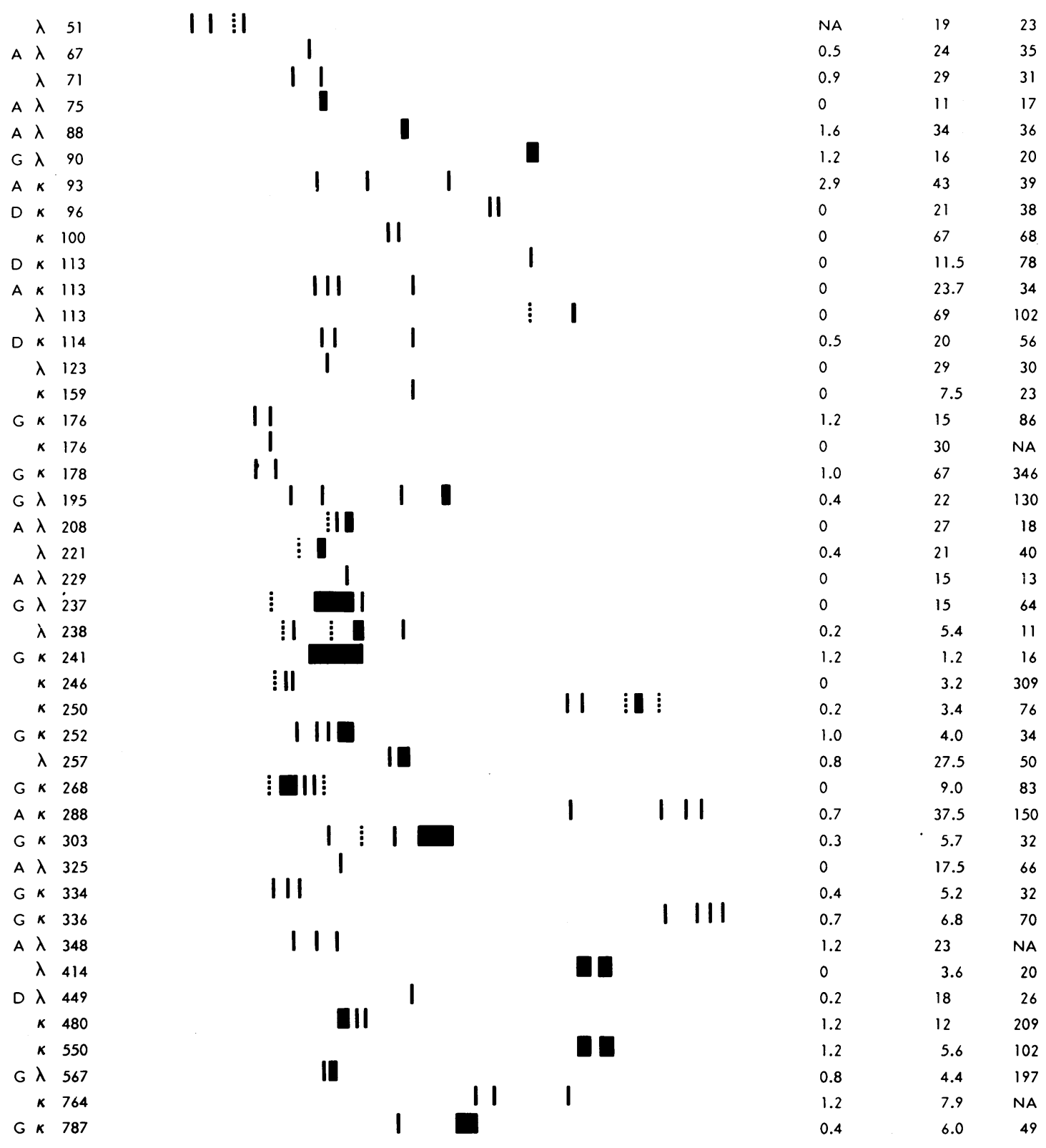

Fig. 1 Data base of study. First column denotes immunoglobulin type A, G, or $D$ of corresponding paraprotein; second column light chain type where $\kappa$ or $\lambda$ are shown alone it is a Bence-Jones proteinuria only myeloma. $S A=$ sialic acid, LC = urinary light chain concentration, $U=$ units (1 unit is equivalent to $1 \mathrm{~g}$ of polyclonal LC standard); $\alpha 1-m=\alpha 1-m i c r o g l o b u l i n$ concentration. 

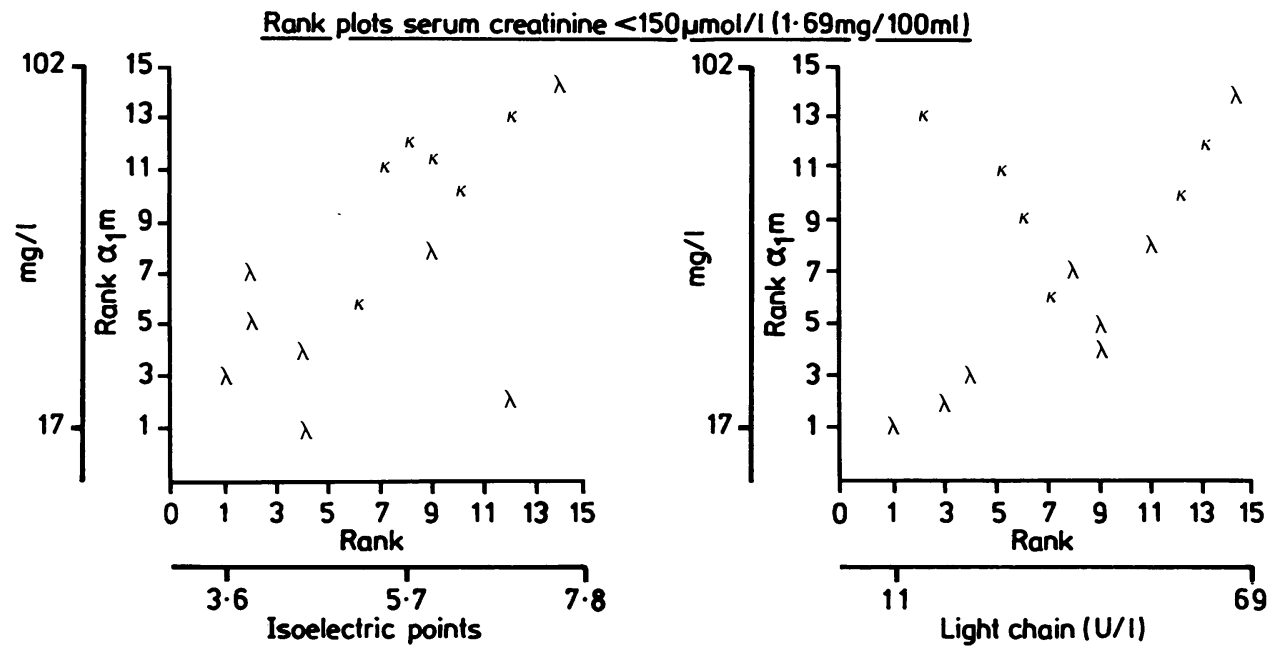

Fig. 2 Rank plot of urinary $\alpha 1-m$ with (a) mid point of urinary light chain spectrotype and (b) urinary light chain excretion in patients with serum creatinine concentration of $<150 \mu \mathrm{mol} / \mathrm{l}(1.6 \mathrm{mg} / 100 \mathrm{ml})$ at presentation.

equivalent levels of light chain production. To see if this heterogeneity was limited to the pI of the light chains, the mid point of the pI spectrotype for each patient was plotted against $\alpha 1$-microglobulinexcretion. Figs. $2 a$ and $b$ show correlations for patients who were not in renal failure at presentation; there was an association between urinary $\alpha 1-\mathrm{m}$ concentrations and urinary light chain $\mathrm{pI}$ in these patients. No such association, however, was seen in the patients presenting with renal failure. Renal failure increases serum $\alpha 1-\mathrm{m}$ concentrations and hence the concentration of $\alpha 1-\mathrm{m}$ in glomerular filtrate. This complicates the analysis in patients in renal failure.

\section{LIGHT CHAIN PI AND RENAL STATE AFTER TREATMENT}

A policy of high fluid intake reverses renal failure in many patients with myelomatosis. ${ }^{10}$ This is not always achieved, however, and some patients fail to respond to high fluid intake. Fig. 3 shows the mid point of urinary pI spectrotypes plotted against response to treatment. No association was seen between reversibility of renal failure and the pI of light chains.

\section{POLYMERISATION OF LIGHT CHAIN AND PI}

The Table shows the distribution of the polymerisation of the light chains determined from the SDSPAGE run under non-reducing conditions. There seems to be no important association between the polymerisation and nephrotoxicity.

\section{Discussion}

Observations of the effects of injecting human myeloma light chains on glomerular function in rats have suggested that the light chains with a basic charge are nephrotoxic. ${ }^{5}$ Coward $e^{2} a^{6}$ reported a correlation between the light chain $\mathrm{pI}$ and glomerular filtration rate in a study of 23 patients excreting light chains in the urine $(6-635 \mathrm{mg} / \mathrm{mol}$ creatinine). Light chains with a basic pI were associated with the greatest renal impairment; but Smolens et $^{7}{ }^{7}$ showed that in rates transplanted with a $\kappa$-producing lymphoma the $\mathrm{pI}$ of the urinary $\kappa$ chains, which varied from 4.3 to 7.6 , did not correlate with the incidence of nephropathy.

Our study has provided evidence of the microheterogeneity of light chains, which might influence their physiochemical behaviour. Evidently, they can exhibit considerable microheterogeneity of charge. A spread of bands on isoelectric focusing of $>0.5 \mathrm{pH}$ units was present in 21 of $43(48.8 \%)$ samples. Conversely, a pI restricted to a single band was seen only in eight of $43(18.6 \%)$ samples. The microheterogeneity varied from two bands separated by a few tenths of a pH unit to four bands spread over $1.5 \mathrm{pH}$ units. A comparable spread of $\mathrm{pI}$ and the presence of multiple bands has been reported by using immunofixation to identify the Bence-Jones proteins after isoelectric focusing. ${ }^{9}$ The density of sialic residues/mol of light chains suggests that they may suffer random loss after synthesis.

Our study does seem to indicate greater tubular 


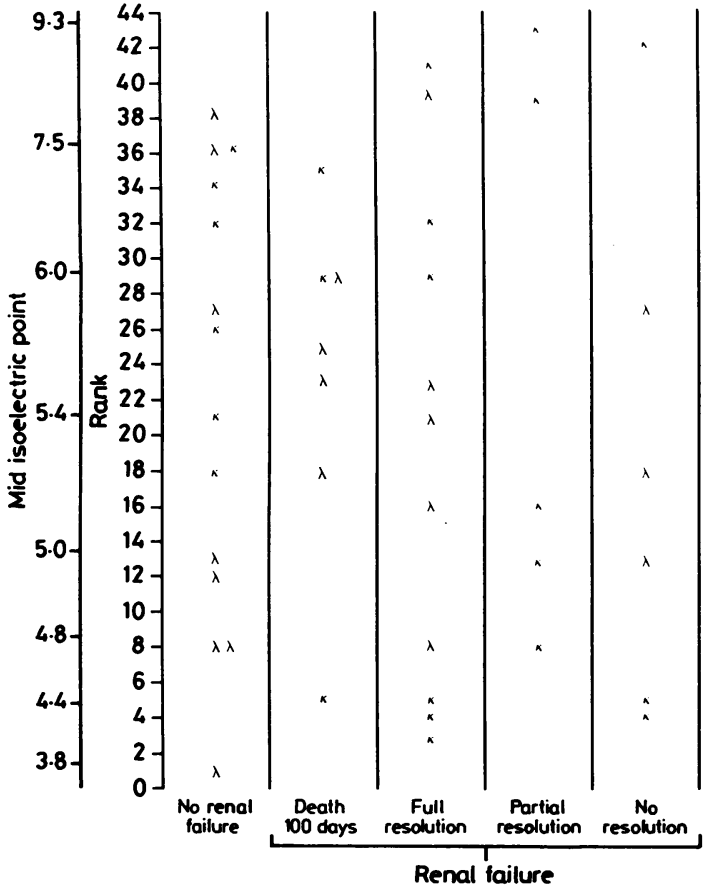

Fig. 3 Relation of clinical course with mid point pI and urinary light chain type in myelomatosis.

dysfunction in those patients whose light chains are more basic. This effect will tend to lower the level of light chain required to induce impairment of proximal tubular dysfunction. All patients in this study, however, had massive light chain proteinuria. This effect may be more pronounced and clinically important in patients with lower levels of light chain in the urine. ${ }^{6}$

No association was seen between the degree of resolution of renal failure and light chain pI. This seems to indicate that $\mathrm{pI}$ is of relatively little importance in the induction of irreversible damage to nephrons in this disease. Some patients show progressive renal failure despite high fluid intake. In these patients the mechanism of renal failure seems likely to differ from that seen in most patients. None of the factors analysed in this study identified a physical characteristic that relates to this progressive form of light chain associated renal damage.

EAJ was supported by a grant from Pharmacia, AB, Uppsala, Sweden. This project was also supported by the Medical Research Council (SP GA2 16939) and equipment was supplied by the Yorkshire Cancer Research Campaign.

\section{References}

${ }^{1}$ Wochner RD, Strober W, Waldmann TA. The role of the kidney in the catabolism of Bence-Jones proteins and immunoglobulin fragments. J Exp Med 1967;126:207-21.

${ }^{2}$ Waldmann TA, Strober W, Mogielnicki RP. The renal handling of low molecular weight proteins: II Disorders of serum protein catabolism in patients with tubular proteinuria, the nephrotic syndrome or uremia. J Clin Invest 1972;51:2162-72.

${ }^{3}$ Maack T, Johnson V, Kau ST, Figueiredo J, Sigulein D. Renal filtration transport and metabolism of low molecular weight proteins: a review. Kidney Int 1979;16:251-70.

${ }^{4}$ Cooper EH, Forbes MA, Crockson RA MacLennan ICM. Proximal renal tubular function in myelomatosis observations in the fourth Medical Research Council trial. J Clin Pathol 1984;37:852-3.

${ }^{5}$ Clyne DH, Pesce AJ, Thompson RE. Nephrotoxicity of Bence Jones protein in the rat. Importance of the isoelectric point. Kidney Int 1979;16:345-52.

${ }^{6}$ Coward RA, Delamore IW, Mallick NP, Robinson EL. The importance of urinary immunoglobulin light chain isoelectric point (pI) in nephrotoxicity in multiple myeloma. Clin Sci 1984;66:229-32.

${ }^{7}$ Smolens P, Venkatachalam M, Stein JH. Myeloma kidney cast nephropathy in a rat model of mutiple myeloma. Kidney Int 1983;24:192-204.

${ }^{8}$ Turner R, Cooper EH, Crockson RA. Separation of light chains in myelomatosis by fast protein liquid chromatography. Protides of the Biological Fluids 1983;31:715-8.

${ }^{9}$ Norden AGW, Fulcher IM, Flynn FV. Detection of Bence-Jones protein by isoelectric focussing of unconcentrated urine followed by nitrocellulose blotting and immunoperoxidase staining. Clin Chim Acta 1985;153:149-56.

${ }^{10}$ Medical Research Council Working Party on leukaemia in adults. Analysis and management of renal failure in fourth MRC myelomatosis trial. $\mathrm{Br}$ Med J 1984;288:1411-5.

${ }^{11}$ Laemmli UK. Cleavage of structural proteins during the assembly of the head of bacteriophage $T_{4}$. Nature (Lond) 1970;227:680-5.

12 Warren $L$. The thiobarbituric acid assay of sialic acids. $J$ Biol Chem 1959;234:1971-5.

Requests for reprints to: Professor EH Cooper, The Unit for Cancer Research, The University, Leeds LS2 9NL, England.

Table Distribution of light chain polymerisation

\begin{tabular}{llllll}
\hline & $\begin{array}{l}\text { No renal } \\
\text { failure }\end{array}$ & Renal failure & & \\
\cline { 2 - 5 } & $\begin{array}{l}\text { Death at } \\
100 \text { days }\end{array}$ & $\begin{array}{l}\text { Full } \\
\text { resolution }\end{array}$ & $\begin{array}{l}\text { Partial } \\
\text { resolution }\end{array}$ & No resolution \\
\hline$\kappa$ & $\begin{array}{l}3 \mathrm{~d}, 2 \mathrm{~m} \mathrm{1d}+\mathrm{m} \\
7 \mathrm{~d}, 1 \mathrm{~d}+\mathrm{m}\end{array}$ & $\begin{array}{l}1 \mathrm{~m}, 1 \mathrm{~d}+\mathrm{m} \\
\mathbf{4 d}\end{array}$ & $\begin{array}{l}\mathbf{4 d}, 2 \mathrm{~d}+\mathrm{m} \\
\mathbf{5 d}\end{array}$ & $\mathbf{2 d}, 2 \mathrm{~m}, 1 \mathrm{~d}+\mathrm{m}$ & $\begin{array}{l}1 \mathrm{~d}, 1 \mathrm{~m}, 1 \mathrm{~d}+\mathrm{m} \\
\mathbf{3 d}\end{array}$ \\
\hline
\end{tabular}

$\mathrm{d}=$ dimer $; \mathrm{m}=$ monomer $\mathrm{d}+\mathrm{m}=$ equal dimer and monomer. 